\section{Performance Appraisal in Public Institutions}

Kamu Kurumlarında Performans Değerlendirmesi

\section{Ramazan TIYEK ${ }^{1}$ Murat TUYSUZ ${ }^{2}$}

Strategic Public Management Journal Volume 7, Issue 14 , pp. 58-76 December 2021

DOI: 10.25069/spmj.1002379

Research Article/Araştırma Makalesi Received: 29.09.2021 Accepted: 27.11.2021

(C) The Author(s) 2021 For reprints and permissions: http://dergipark.gov.tr/spmj

$\ddot{o} z$

Performans değerlendirme, bir örgütte işverenlerin çalışanlardan beklentilerinin ne ölçüde karşılandığını gösteren sonuçları ortaya koymaktadır. Çalı̧̧anların kendi aralarındaki başarı durumlarının listelenmesi, örgütlere kimin ne kadar hizmet ettiğini gösteren sonuçların sunulması açısından da önemlidir. Performans değerlendirmenin örgüte ve yöneticilere sağladı̆̆ faydaların yanı sıra çalışanların kendilerine de birçok faydası bulunmaktadır. Genel olarak klasik ve modern olmak üzere farklı performans değerlendirme yöntemleri bulunmakla birlikte, bunların içerisinden organizasyon yapısına en uygun olanı kullanılmalı ve organizasyon birimlerinin mevcut ihtiyaçlarına göre güncellenmelidir. Herkes tarafindan kabul edilebilecek tek bir doğru performans değerlendirme yöntemi yoktur. Performans değerlendirme sürecinde, performans notları değerlendirme sonunda açıklamalı olarak iletilmesi ve kriterlerin çalışanlara önceden bildirilmesi gerekmektedir. Başarılı bir performans değerlendirme sürecinde, hem değerlendiren hem de değerlendiren ile takdir edilen sınıf düzeyinde anlaşmak çalışan motivasyonuna katkı sağlayacaktır. Hesap verebilirlik düzeyinde çalışan kamu kurumlarında da özel sektörde olduğu gibi çalışanların performansını değerlendiren uygulamalar yaygınlaştırılmalıdır.

Anahtar Kelimeler: Kamu Kurumları, Insan Kaynakları Yönetimi, Performans Değerlendirme

\begin{abstract}
Performance appraisal reveals the results indicating to what extent the expectations of the employers from employees in an organization are met. Listing the success status of the employees among themselves is also important in terms of presenting the results showing who served how much for the organizations. Along with the benefits of performance appraisal for the organization and the managers, it has also many benefits for the employees themselves. In general, there are different performance appraisal methods in the form of classical and modern, but among them, the most suitable one for the structure of the organization must be used and it must be updated for the current needs of the organizational units. There is no single correct performance appraisal method that can be accepted by everyone. In the performance appraisal process, the performance grades should be conveyed in an annotated way at the end of the appraisal as well as the notification of the
\end{abstract}

\footnotetext{
${ }^{1}$ Assoc. Prof. Dr., Kirklareli University, ramazantiyek@gmail.com, https://orcid.org/0000-0002-3442-3517

${ }^{2}$ Dr., Marmara University, murat.tuysuz@marmara.edu.tr, https://orcid.org/0000-0001-5321-0413
} 
criteria to the employees in advance. In the successful performance appraisal process, agreeing both with appraiser and appraise on the appraised grade level will contribute to the employee motivation. Practices appraising the performance of employees should become widespread in public institutions working at accountability level, as in the private sector.

Key Words: Public Institutions, Human Resources Management, Performance Appraisal

\section{INTRODUCTION}

\section{PERFORMANCE APPRAISAL AND PERFORMANCE MANAGEMENT}

Performance means status of success. It is the level of efficiency and productivity towards achieving predetermined objectives. It is the determination and appraisal of the criteria regarding the level of fulfillment of the duties assigned to the employees (Dikmen \& Özpeynirci, 2010: 72). In performance appraisal, the functionality of the roles of employees in achieving the strategic objectives of organizations are measured (Gürüz \& Gürel, 2006: 235). In other words; it is the systematic appraisal of the success and development skills provided by the employees in their work (Seyyar \& Öz, 2007: 308; Sabuncuoğlu, 2005: 184). Performance appraisal is a process that aims to ensure a proper communication between the appraiser (superior) and the appraisee (subordinate) and the employee's self-improvement for the next periods of the work (Russell \& Russell, 2010: 42; Kondrasuk, 2011: 70; Nickson, 2007: 171; Chen \& Eldridge, 2010; 249). In the process, determining performance objectives and performance appraisal criteria, by sharing the performance appraisal, coaching, feedback and determining new objectives with the employees and opportunities to improve performance have an important place (Pace, 2011: 22; Sillup \& Klimberg, 2009: 42). At the beginning of the process, managers should clearly communicate the criteria by which employees will be appraised (Kondrasuk, 2011: 72).

With the performance appraisal, it is aimed for the employees to improve themselves and thus to get ahead of the competitors. It is one of the most important functions of the Human Resources Management in terms of contributing to the development of the employees (Kaymaz, 2009: 83). In order to achieve the aimed success with the performance appraisal, employees should be respected ethically, treated fairly, and should be allowed to appraise their own performance (Sillup \& Klimberg, 2009: 40). Thus, the employee whose performance is appraised will be prevented from making subjective appraisals about his/her own performance and a true performance appraisal grade will be emerged.

Performance appraisal results are effective in making decisions (compensation assessment, location changes, training, promotion, layoff, etc.) that may significantly affect employees in the future. Objective assessment should not be avoided due to the high level of impact on each employee (Pace, 2011: 22). It is possible to ensure the motivation of the employees in the long term when a fair approach is taken with the difficulty of satisfying the employees with the performance appraisal results. The feeling that performance appraisal is done fairly is in direct proportion to make an effort of employees to achieve the goals of the organizations. Coherent application of performance appraisal along with other factors is also important in ensuring the motivation of its 
employees (Gürüz \& Gürel, 2006: 235; Barutçugil, 2002: 125; Dikmen \& Özpeynirci, 2010: 72; Çerçi, 2006 : 4). Performance appraisal creates a link between strategic objectives and corporate outcomes (Mathis \& Jackson, 1997: 340). In order for this connection to function properly, employees must know and understand the goals to be achieved and in addition to the support of managers for the results (Öztürk, 2009: 37-38) they want to achieve, they must give feedback to the employees about their performance and guide them to show better performance (Gomez-Mejia, Balkin \& Cardy, 2004: 223).

In a performance management system (Öztürk, 2009: 32):

- Vision and goals should be shared with all employees,

- Individual goals must be in line with departmental and organizational goals,

- The review process should determine the degree of realization of the determined goals,

- Trainings for the result of review and development should be defined,

- Appraisals should cover the whole process, the results should be implemented with a development plan,

- Performance goals should be measurable, responsibilities should be defined, should be integrated with training targets,

- Appraisal procedures should be related to performance requirements.

\section{BENEFITS OF THE PERFORMANCE APPRAISAL}

Performance appraisal primarily contributes to distinguish between those who work at a sufficient level and those who do not work. Regardless of the work performance, instead of an application where everyone gets the same appraisal score, it is important for the employees to be appreciated by giving a high performance appraisal score in order to ensure their motivation. Organizations with performance appraisal practices have higher levels of achieving successful results. Generally speaking, the benefits of performance appraisal application to the organizations are as follows: (Uyargil, 2013: 11-12):

- The efficiency and profitability of the organization increases,

- The quality of service and production improves,

- Training needs and training budgets are determined more easily and accurately,

- The information required for planning human resources is obtained more reliably,

- The development potential of individuals is determined more accurately,

- Flexibility is provided in meeting short-term human resources needs (caused by absenteeism, labor turnover, etc.).

For the managers who work through others, it is important that not all personnel are appraised at the same level, taking into account the contributions of employees themselves, and in order to achieve predetermined strategic goals.

The benefits of the performance appraisal application to the managers are as follows: (Uyargil, 2013: 11):

- In planning and control functions, they will be more effective so the performance of employees and their units improves,

- Communication and relationships with employees turn into more positive, 
- They identify the strength and developmental needs aspects of the employees more easily and help them in this direction,

- They recognize their own strengths and weaknesses while evaluating their employees,

- While they get to know their employees more, the delegation of authority will be easier,

- They improve their managerial skills or obtain the conditions where they can easily apply these skills.

Performance appraisal is not only important for its success in the organizational field but also for its contribution to the employees. The benefits of performance appraisal for the employees are as follows (Uyargil, 2013: 11; DelPo, 2007: 11; Armstrong, 2006: 496):

- Employees learn what their superiors expect from them and how they appraise their performance,

- Determines how each employee's job can further the overall goals of the organization,

- Identifies and rewards employees to increase loyalty and motivate employees to continue to succeed,

- Maximize the potential of individuals and teams to benefit themselves and the organization by focusing on achieving their goals,

- Employees recognize their strengths and aspects that need improvement,

- Employees understand their roles and responsibilities better within the organization / department,

- Employees develop their sense of job satisfaction and self-trust through the positive feedback they receive on their performance,

- It reduces the risk of complaints and litigation by ensuring that employees are treated fairly and not deviated from management decisions.

\section{THE PERFORMANCE APPRAISAL METHODS}

Performance appraisal methods are various. Along with the needs in working life, many performance appraisal methods have been used in the historical process. Among the methods that can be grouped under two subheadings, classical and modern performance appraisal methods, the method should be applied that best suits the needs and requirements of the organization or the department where the appraisal is made (Sabuncuoğlu, 2000: 172). Although modern methods are at a level that can meet the performance appraisal needs of today's organizational structures, methods should be chosen in line with the purpose of performance appraisal and sometimes different methods or appraisal criteria can be applied among the departments within the organization. For example, while the 'communication' factor may be very important in evaluating the performance of a personnel working in the public relations department, the "carefulness" factor will be more important than the 'communication' factor for a staff working in the accounting department. Therefore, instead of applying a uniform performance appraisal method for all employees, it is necessary to apply the correct performance appraisal method by focusing on the behaviors aimed to be realized.

\subsection{Traditional Performance Appraisal Methods}

Traditional performance appraisal methods consist of the first personnel performance appraisal methods in which the employees are not appraised in a multidimensional and detailed way. 


\subsubsection{Graphic Rating Scales}

In addition to being the oldest appraising method, it is the most common and the most used performance appraisal method due to its ease of application and simplicity. In this method, the names of the personnel whose performance will be appraised are written one under the other in a table, and then there are options such as "poor", "adequate", "commendable", "excellent" and "distinguished" against the names of the persons. It is requested to mark the most appropriate option out of 5 scale appraisal scales for each personnel (Uğur, 2003: 225; Sabuncuoğlu, 2000: 173). It is a frequently preferred method due to the ease of application and the fact that the observation and opinion of the manager outweigh the performance appraisal of the employees. In the graphic rating scales method, while the employees themselves are marked according to predetermined grades, the performance appraisal scores of all employees also appear in the same table (Uğur, 2003: 225). Rather than making a very detailed assessment, a general opinion is expressed about the employees.

\subsubsection{Paired Comparison and Ranking Method}

It is a performance appraisal method that is easy to apply just like the graphic rating scales. Unlike the graphic rating scales, employees are appraised by comparing them in pairs. It can be considered as a more effective method for the workplaces where the number of employees is low due to the comparison of employees with each other. In the paired comparison method, there is no situation that forces the distribution of employees in certain categories (Sabuncuoğlu, 2000: 172; Carrell, Elbert \& Hatfield, 1995: 364). The performance appraisal scores obtained by comparing the employees with each other are then ranked, and the performance appraisal scores of the employees are grouped from the highest to the lowest. As a result of the ranking, human resources functions such as promotion, appointment, reward or layoff are processed. For this purpose, the "simple ranking" technique where appraisers rank the employees from the most successful to the least can be followed, as well as the "paired comparison matrix" where the people to be compared are written on horizontal and vertical lines and paired comparisons are made, the result is ranked from the most signified field to the least one can be used (Uğur, 2003: 225-226).

\subsubsection{Rating Method}

In graphic rating and paired comparison methods, success of employees were generally appraised in terms of criteria such as knowledge, skills, abilities, job adaptation and sense of responsibility. In this method, employees are appraised separately in terms of each criterion (Uğur, 2003: 226).

After determining the important criteria for the position, each criterion within itself is divided into grades such as "poor", "adequate", "commendable", "excellent" and "distinguished" and the employee's status is marked for each criterion in this respect and overall success is obtained (De Cenzo \& Robbins, 1996: 330; Uğur, 2003 : 226). Examples of the criteria used in rating method are: the quality of work, amount of work, job knowledge, initiative, loyalty, judgment, absenteeism, humanistic behavior, commitment, job and work environment fit, responsibility, leadership and training subordinates (Sabuncuoğlu, 2000: 175; De Cenzo \& Robbins, 1996: 330). Although each of the exemplary criteria is important, the most important one is the requirements of the position of the employee. As in the job appraisal, in this method, points are given out of 100 to each criterion and performance appraisal can be done through the points by distributing them to the degrees. Since the criteria created for the position are graded, the rating method is considered to be more objective than other classical performance appraisal methods (Uğur, 2003: 226). 


\subsubsection{Forced Distribution Method}

In the forced distribution method known as the "Checklist Method", appraisers or final appraisers prepare forms that contain short sentences (job involvement, have high skills, absenteeism, etc.) that will help describe employees from various aspects. The forms are given to the managers or appraisers of the employees and the appraisers are asked to choose from these sentences (Uğur, 2003: 228). It is a method in which the employee is appraised in terms of all the characteristics that are valid while doing his/her job (De Cenzo \& Robbins, 1996: 329). The appraiser marks out the many ready-made sentences in this list that are for the suitable person. The positive or negative marked sentences are then appraised by the experts. If desired, specific, different weighted scores can be given according to the importance of each sentence or criterion (Sabuncuoğlu, 2000: 186). Since the score and efficiency of each word group are known only by the experts or the final appraiser, the influence of the managers' preconceptions is prevented thus enabling them to make a more objective assessment (Uğur, 2003: 228).

\subsubsection{Critical Incidents Method}

It is an appraising method made by the managers who are also an appraiser at the same time to constantly monitor their employees closely and to record their work-related behaviors and successes against critical duties or events (Sabuncuoğlu, 2000: 178; Carrell, Elbert \& Hatfield, 1995: 365). This method is based on the remarkable work done at different times in determining the success of the employee. Remarkable jobs called critical incidents can either be positive, such as performing an important service or negative such as performing a damaging action (Uğur, 2003: 228). In this method, critical events must be determined in advance. For example, a salesperson's behavior towards a customer, his/her relationships with his/her teammates and positive and negative job attitudes can be discussed (Sabuncuoğlu, 2000: 179). It is a performance appraising method that focuses on the fundamental behaviors that make the difference between performing a job effectively and ineffectively (De Cenzo \& Robbins, 1996: 329). Regardless of the direction, the time and occurrence of critical events and by whom are noted by the managers and it is ensured that they are taken into account in the performance appraisal (Uğur, 2003: 228-229).

\subsubsection{Field Review Method}

In this method, which is generally performed by the "Human Resources Management" experts of the company, no form or graphic is used. The appraiser observes the employee while on the job and collects the necessary information about his/her performance by asking various questions to his manager. Then, this information is subjected to a systematic appraisal and the performance value of the employee is found. As it reduces the formalities, the field review method preferred by the managers but causes a waste of time as it keeps the employees on the job and psychological pressure (Uğur, 2003: 229).

\subsection{Modern Performance Appraisal Methods}

Contemporary performance appraisal methods appraise employees in many aspects, not only in the position of doing the work assigned to them, but also try to motivate them to do more successfully, and appraise their performance accordingly. Therefore, criteria such as the ability of employees to take initiative, development aspect, suggestion logic, participation in decisions include an important part of performance appraisal (Uğur, 2003: 230). 


\subsubsection{Management by Objectives Method}

According to the management by objectives considered as a management philosophy, management has become a method used in the appraisal of employees today (Uğur, 2003: 230). In this performance appraisal method in which certain goals are set for the employees, the long and short-term goals of the organization must first be determined and then the organizational, departmental and individual goals must be clarified.

In this model, it is possible to achieve all goals in cooperation with employees and managers in order to achieve success (Sabuncuoğlu, 2000: 183). Objectives should be at a level that is easily measurable, objective and acceptable between the parties, rather than interpretative, ambiguous and subjective statements (Carrell, Elbert \& Hatfield, 1995: 368; Uğur, 2003: 231). This dynamic method based on integrating the need to achieve clearly defined goals with the need for contribution and self-improvement of the employees. The power that drives people in this method is not the orders of the managers, but the desire to reach the goal. In this method, it is also an important assumption that all employees know the business objectives and the employees participate in the decision processes. Thus, over time, it is thought that the goals of the organization and the goals of the individual will be integrated (Uğur, 2003: 231).

\subsubsection{Assessment Centers Method}

The Assessment Centers Method consists of teamwork such as leaderless group discussions, role play, document basket, business games, ten-minute discussion. The group of employees can be brought to a place where they can be isolated from the surroundings and tested by various methods from 1 to 3 days (For example, a chalet). At the same time, appraiser who are the managers of the company receive the necessary training, appraise the people (Sabuncuoğlu, 2000: 180). With this method, which is made especially for managers, it is aimed to determine the hidden skills of the personnel as well as their known characteristics and to predict their future performance accordingly (Uğur, 2003: 232). The work of the group, which is formed to solve various problems together, is carried out in an environment called "assessment centers" and the members are monitored one by one by the appraisers and information is gathered about their behaviors and the relationships they establish with each other. In the light of this information gathered, predictions are made about the future performances of individuals (Uğur, 2003: 232).

\subsubsection{Psychotechnics and Psychoanalysis Method}

It is an appraising technique that is generally applied to managers. The reason it applies to managers is that it is expensive and requires a long time (Uğur, 2003: 233). People who are considered to be appraised by psychologists working in the business or external experts are subjected to various psychological tests. Information is also collected through bilateral meetings and observations. This information is mostly the information that characterizes the attitudes and behaviors of individuals such as psychological behavior, mental activities, and emotional aspects. In line with the information obtained, it makes predictions about what the future performance of the employee will be, whether the job and the enterprise will comply with the development perspective and whether it will match with the business culture (Uğur, 2003: 233).

\subsubsection{Degree Appraisal Method}

360 Degree Appraisal Method is one of the contemporary performance appraisal methods and it is an up-todate appraisal method. Employees' performance are appraised in many different ways. In this method, the employee is defined as 360 degrees because it is appraised by people from all aspects such as subordinates, 
superiors, peers, customers, and it is named "360 degree feedback" because the appraisal results are reported to the employee (Ugur, 2003: 233-234). In addition, while determining the score of the performance, which is also appraised by the employee him or herself, the average of the points given is taken. 360 Degree Appraisal mainly appraises aspects such as the leadership of the employees, the level of being a team player, the ability to manage people, self-management, communication, organizational skills, decision-making, expertise and adaptability among the survey questions that make up the performance appraisal method (Armstrong, 2006: 524). Although there are some difficulties in the implementation phase, it has recently become widespread due to the multi-faceted appraisal of employee performance and more realistic results (Uğur, 2003: 235). It has many benefits compared to the other performance appraisal methods such as evaluating the employees in terms of many different people and perspectives, giving more reliable results because they are appraised by more than one person, and providing motivation of employees due to being active in the appraisal process (Armstrong, 2006: 527-528).

\section{FACTORS TO CONSIDER IN PERFORMANCE APPRAISAL}

\subsection{Determination of Performance Appraisal Criteria}

Performance appraisal criteria can be explained as criteria determined for performance appraisal by the workplace management for each job or position (white or blue collar personnel), taking into account the characteristics and conditions of the workplace (Seyyar \& Öz, 2007: 309).

The criteria used in performance appraisal should be included in the job descriptions of the employees. Employees should know the criteria by which they are appraised when they are hired (Megginson, Byrd \& Megginson, 2006: 282). Therefore, job analyzes that contribute to the establishment of the duties and responsibilities of the employees in the workplace must be done before determining the performance appraisal criteria (Sabuncuoğlu, 2005: 187).

Performance appraisal criteria created within the framework of job analysis and job descriptions should be clear and clear enough to be understood equally by everyone (Chen \& Eldridge, 2010: 251; Brown, Hyatt \& Benson, 2010: 380).One of the most important elements that Human Resources Managers should do in determining performance appraisal criteria is contribute to the determination of the criteria (Jandt, 1998: 160).

\subsection{Appraisers}

Performance appraisal should be done by the closest manager who knows the employees best and has the chance to observe the entire performance of the employees. Employees should also be allowed to appraise themselves in order to avoid an ethical problem (Sillup \& Klimberg, 2009: 42; Chen \& Eldridge, 2010: 252).

One of the factors that is effective in the misappraisal of employee performance is that managers who are in an appraiser position cannot fulfill their responsibilities properly. Halo effect, novelty effect and central tendency etc. With the effects, the evaluator cannot make the appraisal completely in some cases (Brown, Hyatt \& Benson, 2010: 378). In order for managers not to make subjective appraisals, performance appraisal criteria should be made according to job descriptions and the directive should be prepared objectively (Okakın, 2008: 
107). Before determining the criteria to be used in performance appraisal, those who appraiser and appraisee should be informed about the importance of the issue and where the results will be used should be determined (Barutçugil, 2002: 144; Gürüz \& Gürel, 2006: 239). In addition, the fact that performance appraisal is seen as an ordinary job that provides a waste of time in situations such as when someone's performance is shown to be low in the workplace and declared a scapegoat (Brown, Hyatt, \& Benson, 2010: 378) bothers employees and does not fit the spirit of performance appraisal. Appraisers' failure to give the necessary importance to performance appraisal (low score for everyone, high score for everyone, or equal score for everyone, etc.) leads to false feedback given to employees and therefore to high performance employees being punished (Cascio, 1998: 60). Performance appraisal consists of giving appropriate grades for employees. There should not be a subjectivity assessment such as the tendency to give employees low or high marks.

It is important for people working in appraiser positions to receive a training on performance appraisal in terms of obtaining the desired benefit from the performance appraisal results. In the training, the assignments and responsibilities of the appraisers should be explained in a clear and understandable way (Chen \& Eldridge, $2010 ; 250)$. In this training which will be a source for the correct performance appraisal; basic elements such as the language to be used, objectivity, legal aspect of appraisal, psychological concerns, appraisal criteria, how to fill in appraisal forms and how the employees should be listened to in appraisal interviews should be emphasized (Kondrasuk, 2011: 69; Gürüz \& Gürel, 2006: 238). These trainings should be repeated after each current performance appraisal process.

\subsection{Continuity in Performance Appraisal: Conducting Interim Appraisal (Pilot Appraisal)}

Managers are required to regularly appraise employees' performance through informal feedback throughout the appraisal period, before the end of the term. This situation will create opportunities for the employees to correct themselves before the performance appraisal period arrives (Harvard Business School Press, 2009: 7; Sujanto, 2011; 25). The long-term situation caused by the appraisal periods covering a certain period can also be solved in this way. This will prevent incorrect evaluations or misunderstandings (Gomez-Mejia, Balkin \& Cardy, 2004: 233). Continuous feedback on the employee's performance will also minimize the surprises in the evaluation interviews at the end of the period (Harvard Business School Press, 2009: 13). The timing of the feedback is very important. The feedback will be more effective as soon as the behavior occurs, (Ovson, 2009: 13). A short evaluation can be made right after a meeting, presentation or project work in the organization. When employees rewarded especially work harder, they work hard and more effectively (Hanks, 1999: 170171). Performing only a final appraisal may also cause employees to feel that they are trapped at the end of the period. Considering the time used in periodic performance evaluations, not making interim evaluations may be misleading. There is no need to spend too much time for interim evaluations. "How was it done? How could it be done better?" answering such short questions will help to show the correct performance.

\subsection{The Performance Appraisal and the Performance Appraisal Meeting}

It should not be forgotten that "good practices will bring good results". In the performance appraisal process where the design is made correctly, it is important to make the implementations correctly as well as the design (Chen \& Eldridge, 2010; 246). Considering the working conditions of each organizations, appraisal periods are generally applied twice or four times in a year that can be determined by them. Such time periods can be determined depending on the working conditions, designing to meet the information needs of the employees, 
is important for every organization that wants to reach "high performing employees". At the end of the period, the realization of mutual expectations should be shared in the meeting between the appraiser and the appraisee, employees should not only be appraised, but also be guided (Gomez-Mejia, Balkin \& Cardy, 2001: 241). According to the results of the performance appraisal application, the appraiser should be able to increase the motivation of the employee by conducting performance interviews with the employees (Eraslan \& Algün, 2005: 103). Although today's technological developments provide many advantages in giving feedback in performance appraisal (e-mail, etc.), it is more beneficial to make face-to-face feedbacks in order to understand the responses of the employees (Cox et al. 2011: 53).

The performance appraisal interviews are becoming more important in terms of knowing the current performance of the employee and starting his/her work in the next period positively (Maund, 2001: 575). In the performance appraisal interview, the goals should be focused. Performance results and behaviors should be evaluated together. In addition to performance evaluation, the development of the personnel should also be evaluated (Kondrasuk, 2011: 71; Sabuncuoğlu, 2005: 197; Öztürk, 2009: 55-56). The behaviors desired to be corrected should be explained in detail during the interviews. In cases where it is considered as a waste of time, results may arise in which the employee cannot fully understand the expected behavioral change (Kuzmits, 1986: 163). Supporting observations and impressions with documents are important in terms of perceiving the interview is evaluated objectively (Harvard Business School Press, 2009: 28). Recording and writing the performance appraisal interview are important in terms of seeing the performance status of the employee (Maund, 2001: 575). The quality of the feedback is valuable to the extent it provides motivation of the employees (David, 2011: 23). Instead of negative, destructive criticism, constructive criticism should be made, the employee should be satisfied with the job and the employee should make an effort to change the desired behaviors by providing self-confidence (Cascio, 1998: 79; Jandt, 1998: 48; Annakis, Lobo and Pillay, 2011: 80). It is a big problem that people do not understand the message given, especially because their emotions are involved in the process of receiving negative messages (Bentley, 1999: 100). Instead of emphasizing only positive or only negative behaviors, it is necessary to motivate employees by expressing them in a positive communication language (Kranz, 2010: 10; Schraeder \& Jordan, 2011: 7). The interview should serve employees and managers to understand the same things. Listening to the employee after the manager's own speeches will eliminate the wrong or incomplete understandings (Harvard Business School Press, 2009: 41; Eren, 2010: 355). Performance appraisal interview should not be considered as a factor that causes some bureaucratic procedures and loss of time and is used only in determining how much reward will be received by which employee (Nickson, 2007: 175; Öztürk, 2009: 29). The meeting is an important element for the productivity of the employees and therefore for the development of the organization.

\subsubsection{Receiving the Employee Expectations in the Meeting}

In a study with the participation of managers and employees working in the defense industry, which focuses on technology production, it was concluded that the most important thing in an effective performance evaluation system was that the employees marked the option of "learning the expectations of the managers from them" (Mert, 2011: 103). Employees' expectations which have become as important as managers for the success of an organization, need to be considered and evaluated significantly. Managers should take into account their thoughts and wishes in making decisions concerning employees and seek ways to benefit from 
these thoughts (Eren, 2010: 524). Employees need to know what is expected of them in order to show the required performance (Barutçugil, 2006: 194). It should not be forgotten that employees are human beings (Morgeson, 2011).

Considering the expectations of the employees is important in terms of showing their real performance or increasing their performance (Casson, 2003: 67). In today's rapidly changing conditions, human resources which are considered as the most important factor in creating competition can show their real performance depends on their motivation. In the performance evaluation interview, the result that constructive criticism and employee opinions have a positive effect on the correct performance in the following periods in a mutual interaction process in which the employee is also included (David, 2011: 16) indicates the importance of meeting employee expectations. In order to identify and meet employee expectations correctly, we can list the topics that the personnel want to know in the performance appraisal interview as follows (Kuzmits, 1986: 163; Cascio, 1998: 60):

- Area of responsibility: duty, job and responsibilities,

- The employee feeling that their manager knows their performance,

- Areas with good performance,

- Areas with poor performance,

- Having the chance to evaluate your own ideas and opinions in performance evaluation interviews,

- Aspects that need to be improved: Improving performance with training, coaching or other training practices or other staff development programs.

One of the important practices that must be done in order to meet employee expectations is not to take actions that may disturb employees during performance evaluation meetings. Some of the behaviors that may disturb employees in performance evaluation interviews are as follows (Sujanto, 2011: 25):

- Attacking the employee, not their behavior (You are desperate, cannot improve, etc.),

- Making vague, abstract claims (We don't trust you...),

- Being unable to show an example of their negative behavior,

- Using undefined expressions (You are usually not professional anyway ...),

- Failure to provide a clear direction in the employee's behavior (You need to improve his attitude etc.).

It should be ensured that the performance appraisal interview is conducted in a planned manner and the employee and the manager should not disturbed during the interview (Jandt, 1998: 163). It should be ensured that employees are being active in the process of receiving feedback. During the performance appraisal meetings, the manager should listen to the employee as much as he/she talks. Otherwise, it will only promote what he/she thinks. But if the employee listens as well, there will be no not fully understood areas that can be called gray areas (Morrison, 1971: 44). Listening to the employee is an important stage in terms of seeing how the statements expressed by the managers are perceived by the employees as well. Questions to be asked to get the opinions of the employees should be asked as open-ended questions that do not end with "yes" or "no". In addition, attention should be paid to the body language of the employees (Öztürk, 2009: 59; Guo, 2009: 11$12)$. 


\section{PERFORMANCE APPRAISAL IN PUBLIC ADMINISTRATION}

Performance appraisal practices are mostly applied in the private sector where competition conditions are more severe and brutal. In recent years, within the framework of increasing the efficiency of public institutions, individual performance has also started to be considered with the aim of improving corporate performance. While the first performance evaluation practices emerge in local governments, where managers are elected for a certain period of time, "Competency-Based Performance Evaluation" is predominantly preferred. Although the Registry Note application has been abolished in Turkish public personnel system, the applications such as 360 Degree Appraisal Method which includes especially the employees in the evaluation process have not been internalized yet.

\subsection{Strategic Management Approach in the Public Institutions}

Although the competition conditions are not brutal compared to the private sector, public institution managers also have responsibilities to fulfill the society they serve. There are areas where they are generally responsible such as auditing whether the income and corporate taxes collected in the society are spent in accordance with the rules, the resources are used efficiently and the level of efficiency of the work is done to achieve the goals (Çevik et al., 2008: 48). Especially after the 1980s, paradigm changes have been experienced in the public administration with the concepts such as total quality management, governance, strategic planning, performance management, together with neo-liberal economic policies. Within the scope of the reforms made in the 2000s, concepts such as strategic management, audit and performance have an important place (Çukurçayır \& Eroğlu, 2004: 41). With the Public Financial Management and Control Law No. 5018, a new form of financial management was accepted in the public administration and the public institutions meeting certain criteria were required to prepare strategic plans. This situation requires management units to set longterm goals together with short-term duties and to use all kinds of resources effectively and efficiently to achieve these goals (Çevik et al., 2008: 48). Thus, it is aimed that public institutions, together with their entrepreneurship and competitiveness characteristics, will carry out activities in accordance with the targets determined at the central level (Eren, 2011: 92). In order to be successfully implemented in public institutions with a strategic planning, a change of mindset must occur. Concepts such as strategy, objective, goal, activity and project have entered the agenda of both public administrators and public employees. Therefore, human resources should be used effectively and efficiently, as well as other resources required for the service or the production (Karasu, 2012: 160).

Concerns about ensuring efficiency in the public administration constitutes the foundation of performance appraisal practices. While doing the job properly, effectively and economically have also become important (Efe, 2012: 121). The understanding of responsibility towards citizens, effective use of resources, diversification and awareness in service demands, the need to ensure coordination between public institutions and the tasks that need to be fulfilled within the framework of the legislation (preparation of job analyzes, standardization of works, formation of a performance measurement system, etc.) explains that it should work within the framework of productivity (Kaya, 2003: 33-39). 


\subsection{Removal of Registry Grade Application}

It is thought that the motivation of employees is ensured with the performance appraisal practices and that private sector organizations are more successful (Behn, 2003: 586). Consequently, the productivity and profitability level of organizations increase (Mert, 2011: 91). The importance of the employees who contribute to the productivity of the organization becomes even greater (Güllüce, 2004: 53). Performance appraisal shapes the behavior of the employees and enables them to realize their own potential. A continuous performance appraisal method should be used for the employees in the organization in order to fulfill their activities more successfully to set their goals and to achieve these goals (Kara, 2009: 57). Performance appraisal practices are needed in terms of determining the targets or competencies for each employee to the extent of their potential and measuring the results of the implementation within this scope, defining the success and the failure, helping the management to correct itself and learn from its mistakes (Akçakaya, 2012: 194).

Evaluation of the success of civil servants working in the public organizations was made with the registry grade application prepared in 1986. With the removal of the registry grade application on 25.02.2011, there is currently no individual performance appraisal applications in the public organizations. In the legislative regulation that abolishes the registry grade application, the condition of "not taking disciplinary punishment" has been stipulated instead of "registry" in articles 64 and 37 of the Civil Servants Law No. 657.

Relevant new articles are as follows (http://www.memurlar.net/haber/217873/):

- The new version of the article 64: "A level progression is applied to civil servants who have not received any disciplinary punishment in the last eight years, to be taken into account in raising their salary degrees."

- The new version of the article 37: "According to the provisions of this law, the earned right pensions of those who are entitled to receive pensions from the fourth grade of the degrees they can increase to the maximum in terms of their education status, service classes and job titles and who have not received any disciplinary punishment in the last eight years are upgraded to a higher degree without seeking a position requirement."

As can be seen, it is difficult to say that the registry grade application directly reflects the success of the employees in their work. In the regulation made after the abolition of the registry grade, instead of the "registry grade", "the condition of not taking any disciplinary punishment" is taken into account in the progress of the employees. Although not taking any disciplinary action is important, practices that encourage individual employees are needed. Human resources have by public institutions are of great importance for administrations to produce successful and effective services. For this reason, it is important to develop the understanding of human resources management and to establish a good performance evaluation system (Coşkun \& Şekercioğlu, 2011: 44). Performance management and therefore evaluation of employees' individual performance will enable public institutions to work efficiently (Efe, 2012: 125). The wage corresponding to the labor of the employee can be evaluated differently in terms of employees of private sector and public sector organizations. So to speak, when employees in private sector enterprises do not do their jobs, they will not receive their wages when the organization they work for shuts down or goes to retrenchment as a result of the loss. In public institutions, whether employees work more or less does not cause any change in their wages (Çukurçayır, 2003: 
146). Although it is important for employees to have a job security, designing and managing them in a way that may cause low productivity can affect corporate efficiency. With the Public Financial Management and Control Law No. 5018, it is aimed that public institutions have to renew themselves, get rid of the cumbersome and bureaucratic structure and turn them into functional, transparent and citizen-oriented structures (Çukurçayır, 2009: 31). In this process, the importance of human resources working efficiently and effectively is more than previous periods. Determining performance goals for employees and measuring them are important in terms of the functionality of the bureaucratic public structure. Performance appraisal is the measurement of the efforts and success of employees in the workplace. It is important in terms of distinguishing those who are successful by making more effort in their job and those who do not. Employees should also adopt the same strategic insights of those in executive positions and implement successful practices. One of these applications is performance appraisal applied to distinguish between employees who works adequately and not. At the end of the performance appraisal, it is expected that those who show superior performance will be rewarded to increase their performance and those who show inferior performance will improve their performance as a result of the warnings made to them.

\section{CONCLUSION}

Motivating employees can be accomplished by meeting their needs. Employees' needs consist of elements that will mobilize and motivate them (Megginson, Byrd, \& Megginson, 2006: 279-280). One of the most important practices that will increase the productivity of the employees and make their development is to appraise them periodically. The equivalent of this in the literature is performance evaluation. The goal in the performance management is to create and implement an evaluation process that can satisfy everyone (Sujanto, 2011; 26). Managers must first be sure that they are doing their part to show the performance they expect from their employees. Employee expectations that are designed in managers' own minds have to be expressed employees very well. Besides, they must guide them by considering the training and development activities that employees should take in order to do their jobs better and helping their employees to gain self-confidence by praising their positive behaviors instead of lowering their motivation by highlighting only their negative behaviors. Employees must also follow the behaviors that are expected from them. Employees should want to learn how their performance is perceived by their managers as well as themselves, they should think that they are not only the listener but a party to the meeting in performance appraisal interviews, they should be in constant communication with their manager about the implementation of performance enhancing practices, and they should take the necessary steps to do what needs to be done without waiting for the end of the term. It is understood that many problems related to performance appraisal in working life can be solved through communication. Reasons like unaware of the performance appraisal criteria of employees and not taking the defense of a low performance alleged employee are the behaviors that hurt the spirit of performance appraisal and damage employee and organizational development. Performance appraisal should be used as a measure to increase organizational efficiency, not as a means of firing employees. Because employees are the only implementers of each original project in the minds of the employers. In other words, they are the biggest partners of employers. Employees must have the information they need to know and managers must know what kind of expectations they have from them and act accordingly. No matter how perfect the performance appraisal criteria are, if the management skills of the appraisers who are its implementers are not sufficient, it will not be a very successful application. Because some minor communication mistakes that are ignored may cause indirect 
costs to the organization such as insufficient performance of the employees for a period of time and leaving the job etc.

In order to successfully manage the performance appraisal, attention should be paid to the following:

- The performance appraisal system is not a punishmental tool. It only evaluates employees according to their job successes. Both managers and employees should have this point of view for running the system properly.

- In order to internalize the understanding of the performance evaluation system for the employees and the managers, which is an important criterion to distinguish the personnel who perform their job properly or not, some activities must be carried out for the creating awareness about the system.

- Managers should be trained and informed about what they should or should not do in the performance appraisal process. In the performance appraisal process, the importance should be given to the subject of "training of appraiser". A successful performance appraisal should start from the beginning of what needs to be done about performance appraisal.

- It is important to determine the performance appraisal criteria together with the employees and to ensure that the employees know which criteria they are evaluated so that their motivation will be established according to the appraisal. Employees who know the criteria that evaluate them are expected to act in accordance with the expectations of their managers.

- In addition to the performance appraisals at the end of the period, the feedback should be given to the employees about how they work through the interim appraisals during the period. Feedbacks are important for the employees to understand what is expected from them and to improve their performance. The importance of such evaluations can be considered as a waste of time at first however it is better understood when employees show a successful performance at the end of the period.

- In performance appraisal interviews, instead of subjective statements objective statements and supporting information and documents should be included. To keep documents considered important, a care should be taken about employee performance.

- Employees should definitely be given the right to speak in performance appraisal interviews and they should be ensured to express what is expected of them in their own words. This will show whether the employee has correctly understood the expected behaviors in the future period.

- During the performance appraisal meetings or at any time of working life It should not be forgotten that managers have an obligation to protect the employees in addition to the duty of doing the job and loyalty of the employee and it should not be overlooked that the parties should understand each other in line with these principles. The employees who have the same goal should be helped and motivated to reach the information they need for the high performing employees and organizations. 


\section{REFERENCES}

Akçakaya, Murat (2012). "Kamu Sektöründe Performans Yönetimi ve Uygulamada Karşılaşılan Sorunlar" Karadeniz Araştırmaları, Sayı 32, 171-202.

Annakis, John; Antonio Lobo ve Soma Pillay (2011). Exploring Monitoring, Work Environment and Flexibility as Predictors of Job Satisfaction within Australian Call Centres, International Journal of Besiness and Management, Cilt: 6, Say1: 8, 75-93.

Armstrong, Michael (2006). A Handbook of Human Resource Management Practice (10th Edition), London: Kogan Page.

Barutçugil, İsmet (2002). Performans Yönetimi, 2. Bask1, İstanbul: Kariyer Yayınları.

Barutçugil, İsmet (2006). Yöneticinin Yönetimi, Kariyer yayınları, İstanbul.

Behn, Robert D. (2003). “Why Measure Performance? Different Purposes Require Different Measures”, Public Administration Review, Cilt 63, Say1 5, 586-606.

Bentley, Trevor (1999). İnsanları Motive Etme (Çev. Onur Yıldırım), Hayat Yayınları, İstanbul.

Brown, Michelle; Douglas Hyatt ve John Benson (2010). "Consequences of the Performance Appraisal Experience", Personnel Review, Cilt: 39, Sayı: 3.

Carrell, Michael R.; Norbert F. Elbert ve Robert D. Hatfield (1995). Human Resource Management: Global Strategies for Managing A Diverse Workforce, New Jersey: Prentice-Hall.

Cascio, Wayne F. (1998). Applied Psychology in Human Resource Management, 5. Bask1, Upper Saddle River: Prentice Hall.

Casson, Herbert N. (2003). İnsan Yönetme Sanat1, (Çev. Özcan Ünlü), İstanbul: Hayat Yayınları.

Chen, Jie ve Derek Eldridge (2010). Are "standardized performance appraisal practices" really preferred? A Case Study in China, Chinese Management Studies, Say1: 4, No:3, 244-257.

Coşkun, Bayram, ve Lale Sanem Şekercioğlu (2011). Belediyelerde Bireysel Performans Değerlendirme: İzmir İli İlçe Belediyelerinin İncelenmesi”, Dokuz Eylül Üniversitesi Sosyal Bilimler Enstitüsü Dergisi, Cilt 13, Sayı 2, 43-64.

Cox, Susie S.; Laure E. Marler; Marcia J. Simmering ve Jeff W. Totten (2011). Giving Feedback: Developlment of Scales fort he Mum Effect, Discomfort Giving Feedback, and Feedback Medium Preference, Performance Improvement Quarterly, Cilt: 23, Say1: 4, 49-69.

Çerçi, Orhan (2006). Polis Performans Yönetimi, Ankara: Emniyet Genel Müdürlüğü Basımevi. 
Çevik, H. Hüseyin; Turgut Göksu; Veysel K. Bilgiç; Muhittin Karakaya; Kazım Seyhan ve Serdar Kenan Gül (2008). Kamu Kurumlarında Performans Yönetimi, Ankara: Seçkin Yayınları.

Çukurçayır, M. Akif (2003).Yurttaş Odaklı Yerel Yönetim, Konya: Çizgi Kitabevi.

Çukurçayır, M. Akif (2009). "Yerel Yönetimde Değişim: Bürokratik Örgütten Hizmet İşletmesine Doğru”, Sayıştay Dergisi, Sayı 73, 31-49.

Çukurçayır, M. Akif, ve Tuğba Eroğlu (2004). "Yerel Yönetimlerde Yeniden Yapılanmaya Farklı Bir Yaklaşım: Verimlilik ve Başarı Karnesi (Balanced Scorecard)”, Sayıştay Dergisi, Sayı 53, 41-67.

David, Emily (2011). Examining the Role of Narrative Performance Appraisal Comments on Performance Change, Houston Üniversitesi, Psikoloji Bölümü, Felsefe Doktora Tezi

De Cenzo, David A. ve Stephen P. Robbins (1996). Human Resource Management (Fifth Edition), New York: John Wiley \& Sons.

DelPo, Amy (2007). The Performance Appraisal Handbook (2nd Edition), USA: Nolo.

Dikmen, Burcu ve Özgür Özpeynirci (2010). “Matris Tipi Örgütlerde Bireysel Performans Değerlendirme: 360 Derece Yöntemi ve Hedeflerle Yönetim Teknikleri ile Melez Bir Yöntem Uygulaması”, H.Ü. İktisadi ve İdari Bilimler Dergisi, Cilt: 28, Sayı: 1, 71-104.

Efe, Şeref (2012). "Kamuda Stratejik Planlamaya Dayalı Performans Yönetimi: Türkiye Uygulaması ve Sorunlar”, Sayıştay Dergisi, Sayı 87, 121-142.

Eraslan, Ergün ve Onur Algün (2005). “İdeal Performans Değerlendirme Formu Tasarımında Analitik Hiyerarşi Yöntemi Yaklaşımı”, Gazi Üniversitesi Mühedislik ve Mimarlık Fakültesi Dergisi, Cilt 20, No 1. 95-106.

Eren, Erol (2010). Örgütsel Davranış ve Yönetim Psikolojisi, 12. Baskı, İstanbul: Beta Yayınları.

Gomez-Mejia, Luis R., David B. Balkin ve Robert L. Cardy (2001). Managing Human Resources, 3. Bask1, New Jersey: Prentice Hall.

Gomez-Mejia, Luis R., David B. Balkin ve Robert L. Cardy (2004). Managing Human Resources, 4. Bask1, New Jersey: Prentice Hall.

Guo, Kristina L. (2009). "Effective Communication in Health Care: Strategies to Improve Communication Skills for Managers", The Business Review, Cilt: 12, Sayı: 2.

Güllüce, İdris (2004). Yerel Yönetimlerin Sorunları ve Çözüm Önerileri, İstanbul: Alfa Yayınları.

Gürüz, Demet ve Emet Gürel (2006). Yönetim ve Organizasyon, Ankara: Nobel Yayınları.

Hanks, Kurt (1999). İnsanları Motive Etme Sanatı, (Çev. Can İkizler), Alfa Yayınları, İstanbul. 
Harvard Business School Press (2009). Performans Değerlendirmesi, (Çev. Melis İnan), Optimist Yayınları, İstanbul.

Jandt, Fred E. (1998). Yönetim Sorunlarına Etkili Çözümler (Çev. Levent Akın ve Vedat G. Diker), İstanbul: Hayat Yayınları.

Kara, Derya (2009). “Uygulanan Performans Değerlendirme Yöntemlerinin Yöneticilerin Ulaşmak İstedikleri Amaca Etkisi”, İşletme Araştırmaları Dergisi, Cilt 1, Sayı “, 53-64.

Karasu, Mihat Arman (2012). "Büyükşehir Belediyelerinde Stratejik Planlama”, Uluslararası Yönetim İktisat ve İşletme Dergisi, Cilt 8, Sayı 16, 159-180.

Kaya, Erol (2003). Belediyelerde Toplam Kalite Yönetimi ve ISO 9001, İstanbul: İlke Yayınları.

Kaymaz, Kurtuluş (2009). Performans Değerleme ve Çalışan Verimliliği, Bursa: Dora Yayınları

Kondrasuk, Jack N. (2011). The Ideal Performance Appraisal is A Format, Not A Form, Proceedings of the Academy of Strategic Management, Cilt: 10, Sayı: 1. 61-75.

Kranz, Garry (2010). “Employees Want Feedback: Even If It's Negative”, Workforce Management, Cilt: 89, Say1: 2.

Kuzmits, Frank E. (1986). Experiential Exercises in Personnel/Human Resource Management, 2. Bask1, Ohio:Merrill Publishing.

Mathis, Robert L., ve John H. Jackson (1997). Human Resource Management (8. Bask1), Minneapolis: St. Paul.

Maund, Linda (2001). An Introduction to Human Resource Management: Theory and Practice, New York: Palgrave.

Megginson, Leon C.; Mary Jane Byrd ve William L. Megginson (2006). Small Business Management: An Entrepreneur's Guidebook (5. Bask1), Boston: McGraw-Hill.

Mert, İbrahim Sani (2011). "Çalışanların Performans Değerlendirme Sisteminin Çıktı ve Engellerine Yönelik Algıları”, Business and Economics Research Journal, Cilt 2, Sayı 3, 87-108.

Morgeson, Frederick P. (Editör) (2011). Personnel are People, Personnel Psychology, Sayı: 64, 1-5.

Morrison, James, Harris (1971). The Human Side of Management, Reading: Addison Wesley.

Nickson, Dennis (2007). Human Resource Management For the Hospitality and Tourism Industries, Amsterdam:Boston Butterworth-Heinemann.

Okakın, Neslihan (2008). Çalışma Yaşamında İnsan Kaynakları Yönetimi, Beta Yayınları, İstanbul. 
Ovson, Alan (2009). The Art of Feedback, California CPA, Cilt: 78, Sayı: 3.

Öztürk, Ümit (2009). Performans Yönetimi, İstabul: Alfa Yayınları.

Pace, Ann (2011). The Performance Management Dilemma, Training and Development, Cilt: 65, Say1: 7.

Russell, Jeffrey, ve Linda Russell (2010). "The Next Level of Performance Management”, Training and Development, Cilt 64, Say1 4, 42-48.

Sabuncuoğlu, Zeyyat (2000). İnsan Kaynakları Yönetimi, Bursa: Ezgi Kitabevi.

Sabuncuoğlu, Zeyyat (2005). İnsan Kaynakları Yönetimi Uygulamalı, 2. Baskı, Bursa: Furkan Ofset.

Sabuncuoğlu, Zeyyat ve Melek Tüz (2005). Örgütsel Psikoloji, Bursa: Furkan Ofset.

Schraeder, Mike ve Mark Jordan (2011). "Managing Performance: A Practical Performance on Managing Employee Performance", The Journal of Quality and Participation, Cilt: 34, Sayı: 2.

Seyyar, Ali ve Cihan Selek Öz (2007). İnsan Kaynakları Terimleri Ansiklopedik Sözlük, Sakarya: Değişim Kitabevi.

Sillup, George P., ve Ronald Klimberg (2009). “Assessing The Ethics of Performance Appraisal Systems”, Journal of Management Development, Cilt 29, Sayı 1, 38-55.

Sujanto, Leigh (2011). Performance Anxiety, Charter, 82,3.

Uğur, Adem (2003). İnsan Kaynakları Yönetimi, Sakarya: Sakarya Kitabevi.

Uyargil, Cavide (2013). Performans Yönetim Sistemi (3. Baskı), İstanbul: Beta Yayınları. 